\author{
S. Kopashynskii ${ }^{1}$, O. Serpukhov ${ }^{2}$, H. Makogon ${ }^{2}$, S. Guba ${ }^{2}$, O. Isakov ${ }^{2}$, Yu. Babkin², O. Klimov \\ ${ }^{1}$ The National Defense University of Ukraine named after Ivan Cherniakhovskyi, Kyiv, Ukraine \\ ${ }^{2}$ Military Institute of Tank Troops of National Technical University, Kharkiv, Ukraine
}

\title{
JUSTIFICATION OF RECOMMENDATIONS FOR IMPROVING THE FUNCTIONING OF THE ARMORED WEAPONS AND MILITARY EQUIPMENT RECOVERY SYSTEM BASED ON THE STUDY OF THE GRAPHICAL NETWORK MODEL
}

\begin{abstract}
The subject matter of the article is the functioning process of the armored weapons and military equipment recovery system during combat operations in modern conditions. The goal of the study is to justify of recommendations for improving the functioning of the recovery armored weapons and military equipment under the order to reduce the time of work and rational use of forces and resources. The tasks to be solved are: to present the process of functioning of the system of armored weapons recovery and military equipment as a list of events and works that comprehensively reflect its essence and the interrelations between individual actions; to build a network graphical model of functioning of the armored weapons and military equipment recovery system of the assigned units; to analyze the critical path of network grapHhics; to identify critical work requiring closer scrutiny and identification of issues and risks that may impact the functioning of the whole recovery system, by analyzing and optimizing the network schedule make suggestions for improving the operation of the recovery armored weapons and military equipment system. General scientific and special methods of scientific knowledge are used. The following results are obtained. It was simulated the functioning of the armored weapons and military equipment recovery system of military units in performing their tasks by constructing a graphical network models critical path. Analysis network diagram allowed us to determine directions of improvement of functioning of system of recovery of armored weapons and military equipment under the conditions of limited material and nonmaterial resources and regular information updates. Conclusions. The network graphic model of the for restoring armored weapons and military equipment recovery of during combat operations it possible to present the entire scope of work, their logical and chronological relationship and to adjust plans taking into account the limited time and insufficient number and training of personnel. Analysis of the critical path of the network schedule makes it possible to conclude that if there are several battalions in the brigade, the repair of samples of armored weapons and military equipment with a labor intensity of more than 200 people / hour is on the critical path because the forces and means for the restoration of armored weapons and military equipment not enough in modern conditions. The network schedule for the recovery of armored weapons and military equipment with the functional distribution of the volume and list of works is optimal for the length of the critical path. The practical implementation of proposals to improve the functioning of the armored weapons and military equipment recovery system is possible by creating separate logistics units of the appropriate hierarchy levels and implementing an interspecific territorial system for providing military units.
\end{abstract}

Keywords: recovery of armored weapons and milllitary equipment, network schedule, logistic approach.

\section{Introduction}

Formulation of the problem and research tasks. The combat experience of the use of troops during the Joint Force Operation indicates that the restoration of armored weapons and military equipment (AWME) is the main source of replenishment of its loss directly during the hostilities (march) and consists in the implementation of a set of organizational and technical measures (works) aimed to bring weapons and equipment samples out of order, ready for use with the return to service, which as a whole forms a unified system for the restoration of armored vehicles weapons and equipment.

The goal of the recovery system is to provide the necessary volume and rate of return to the units of the damaged equipment and weapons and is achieved by purposeful management of its operation and in the general case is reduced to the creation of a rational plan for carrying out a complex of works consists of the interdependent actions of forces and means of troops, repair units which are part of repair and restoration units (subdivisions) of formations (parts) as well as warehouses of armored property. The above testifies to the relevance of the study and the need to formulate an approach to the organization of the functioning of the armored weapons and equipment recovery system based on the combination of scientific methods and advanced information technologies to calculate and justify the decision made under the conditions of limited material and nonmaterial resources and regular information updates.

Analysis of recent research and publications on the issues mentioned above, confirms the relevance of this issue.

According to experts, the inconsistency of the capabilities of the forces and means of repair and restoration units of technical support to the goals and tasks of the Land Forces logistical support system leads to the fact that the existing AWME recovery system doesn't fully provide the needs of the military departments in performing their assigned tasks, therefore there is a need to improve the organizational structure of the repair authorities, on the basis of the system approach and the search for a model of functioning which would provide optimal distribution of forces and means in the shortest recovery time AWME and return it into unit [1-6].

The goal of this issue is to justify of recommendations for improving the functioning of the recovery armored weapons and military equipment under the order to reduce the time of work and rational use of forces and resources. To achieve this goal the following research tasks are solved: to present the 
process of functioning of the system of armored weapons recovery and military equipment as a list of events and works that comprehensively reflect its essence and the interrelations between individual actions, to build a network graphical model of functioning of the armored weapons and military equipment recovery system of the assigned units; to analyze the critical path of network graphics; to identify critical work requiring closer scrutiny and identification of issues and risks that may impact the functioning of the whole recovery system, by analyzing and optimizing the network schedule make suggestions for improving the operation of the armored weapons and military equipment recovery system.

\section{Main material}

1. Building a graphical network model of functioning of the armored weapons and military equipment recovery system. Network planning is considered to be the general tool of project management allows you to make the most effective use of both the production capacity of the repair and restore agencies and the available stocks of military-technical equipment. Based on the application of graph theory using a network diagram, modeling the process of AWME restoration of military units when performing their intended tasks makes it possible to present the entire scope of work and its logical and chronological relationship. It also allow to create a solution to restore AWME on different levels of the hierarchy; to determine and mobilize time reserves; to prevent possible disruptions in the course of work, to implement operational control of deadlines, and, if necessary, adjust plans taking into account limited time and insufficient number and training of personnel.

As you know, the graphical network model [7] is represented as a directed graph (actually called a network graph), whose elements are two logical elements-work and event. The work expresses the performance of a specific event and is divided into work-action and work-expectation (fictitious work).

Work-action will be called a process that occurs over time and is associated with the expenditure of time and resources (material or non-material), so it always has a beginning and an end. It translates one event into another and is shown as a solid line with an arrow on the network graph. To build a network schedule for the operation of the AWME recovery system, we will define the following actions:

- technical intelligence;

- evacuation of a sample of equipment;

- protection, security and defense measures;

- towing of damaged equipment;

- field repair of equipment "on the spot";

- current repair of AWME samples;

- defects detection;

- simple average repair of AWME samples with a labor intensity up to 200 people / hour;

- complex average repair of AWME samples with a labor intensity more than 200 people / hour;

- overhaul of AWME samples;

- returning of the AWME sample to the division;
- military technical equipment resupply;

As military technical equipment resupply is timeconsuming, it is suggested that you enter a standby job that carries the event over time:

- getting military-technical equipment from the warehouse.

On the network graph such work is also represented by a solid line with an arrow. Dependencies (fictitious works) that show a logical relationship between two or more events, but do not require resource and time costs, are not considered in this model.

The initial and final work, that is, the beginning and end of a certain event, is called events. An event is indicated by a circle with a number inside that defines its number.

Among the events, the initial and final events are distinguished. The initial event does not have any previous activities or events related to those reflected in the network model of the work package. The final event does not have the following jobs and events. The initial and final work, that is, the beginning and end of a certain event, is called events. An event is indicated by a circle with a number inside that defines its number.

Among the events, the initial and final events are distinguished. The initial event does not have any previous activities or events related to those reflected in the network model of the work package. The final event does not have the following works and events.

Thus, the process of restoring AWME can be described in a list of events and activities that comprehensively reflect its essence and the relationship between individual measures. The set of works to restore AWME in the terms of the network schedule is presented in Table 1.

As it is known, the armored weapons and military equipment recovery includes, in the general case, technical intelligence, evacuation, transfer of undeveloped weapons repair stock (weapons and military equipment that cannot be restored on their own) to the funds of the senior chief, repair (restoration of combat capability) of weapons and military equipment, bringing them to a combat ready state, returning to service (to units). owever, It is proposed to add to the standard list of events that'll take into account necessarity of waiting for military-technical equipment resupply.

The classic theory of network planning and management allows to optimize the graph to reduce the time spent on work and the rational use of forces and resources. To do this, each work must be matched by some numerical estimate that characterizes its duration.

Given the specifics of the subject matter for some works, it is suggested to use the complexity of the works as numerical estimates.

For example, the complexity of current repairs is 10 people / hours workload, simple average repair - up to 200 people / hours workload, complex average repair - more than 200 people / hours workload, etc.

The division personnel, data on the possibility of repair and restoration units of the certain hierarchy level, statistical data on the AWME failure are indicated in the guidance documents [8]. 
Table 1 - The set of works to restore AWME

\begin{tabular}{|l|l|l|l|}
\hline No. & $\begin{array}{c}\text { Event } \\
\text { number }\end{array}$ & $\begin{array}{l}\text { Work } \\
\text { umber }\end{array}$ & \multicolumn{1}{c|}{$\begin{array}{c}\text { Name and content } \\
\text { of the works }\end{array}$} \\
\hline 1 & 1 & 0 & Beginning \\
\hline 2 & 2 & $1-2$ & Technical intelligence \\
\hline 3 & 3 & $2-3$ & Evacuation of a sample of equipment \\
\hline 4 & 4 & $3-4$ & Field repair of equipment "on the spot" \\
\hline 5 & 7 & $7-4$ & Field repair of equipment "on the spot" \\
\hline 6 & 5 & $3-5$ & Towing of damaged equipment \\
\hline 7 & 6 & $3-6$ & $\begin{array}{l}\text { Protection, security and defense } \\
\text { measures }\end{array}$ \\
\hline 8 & 7 & $3-7$ ' & $\begin{array}{l}\text { Waiting for military-technical } \\
\text { equipment resupply }\end{array}$ \\
\hline 9 & 8 & $5-8$ & Defects detection \\
\hline 10 & 8 & $6-8$ & Defects detection \\
\hline 11 & 13 & $4-13$ & $\begin{array}{l}\text { Returning a sample of equipment to } \\
\text { the division }\end{array}$ \\
\hline 12 & 9 & $7-9$ & Current repair of AWME samples \\
\hline 13 & 10 & $7-10$ & $\begin{array}{l}\text { Simple average repair of AWME } \\
\text { samples }\end{array}$ \\
\hline 14 & 7 & $8-7$ ' & $\begin{array}{l}\text { Waiting for military-technical } \\
\text { equipment resupply }\end{array}$ \\
\hline 15 & 7 & $7 '-7$ & $\begin{array}{l}\text { Military-technical equipment } \\
\text { resupply }\end{array}$ \\
\hline 16 & 9 & $8-9$ & Current repair of AWME samples \\
\hline 17 & 10 & $8-10$ & $\begin{array}{l}\text { Simple average repair of AWME } \\
\text { samples }\end{array}$ \\
\hline 18 & 11 & $8-11$ & $\begin{array}{l}\text { Complex average repair of AWME } \\
\text { samples }\end{array}$ \\
\hline 19 & 12 & $8-12$ & Overhaul of AWME samples \\
\hline 20 & 13 & $10-13$ & $\begin{array}{l}\text { Returning of the AWME sample to } \\
\text { the division }\end{array}$ \\
\hline 21 & 13 & $11-13$ & $\begin{array}{l}\text { Returning of the AWME sample to } \\
\text { the division }\end{array}$ \\
\hline 22 & 13 & $12-13$ & $\begin{array}{l}\text { Returning of the AWME sample to } \\
\text { the division }\end{array}$ \\
\hline 23 & 14 & $13-14$ & End \\
\hline
\end{tabular}

2. Optimization of network schedule for AWME recovery. As we can see, if several battalions are part of a brigade, AWME samples repair with a workload of more than 200 people / $\mathrm{h}$ is on the critical path, and the forces and means at the level of a operational grouping of troops (forces) are not enough to restore AWME samples in modern conditions.

The given data unambiguously signify the triviality of the work, ale to the given statutes are indicated more detailed, to conduct such a work.

Fig. 1 shows a fragment of a network graph of simulation of the process of reconstruction of a tank (mechanized) battalion, which performs tasks as assigned to the brigade. To simplify the presentation of the material, we'll assume that for each battalion that is part of the brigade, the complex of BTOT reconstruction works is similar to the accuracy of the equipment of the armored tank $(\mathrm{t})$ or mechanized $(\mathrm{m})$ battalion.

Waiting for military-technical equipment resupply is time-consuming, so we will assume that its events are fictitious.

An analysis of the constructed network schedule makes it possible to determine what works are on a critical path, that is, need more careful monitoring and identification of problems and risks that may affect the functioning of the entire recovery system.

Typically, network scheduling optimization is offered by redistributing resources from non-critical work to critical work, using additional resources, and reducing the duration of some critical work by involving other professionals [7], and the most "dangerous" for "getting in" "On the critical path are the events of numbers 10, 11 and 12. In the terminology of AWME recovery these proposals can be formulated as follows:

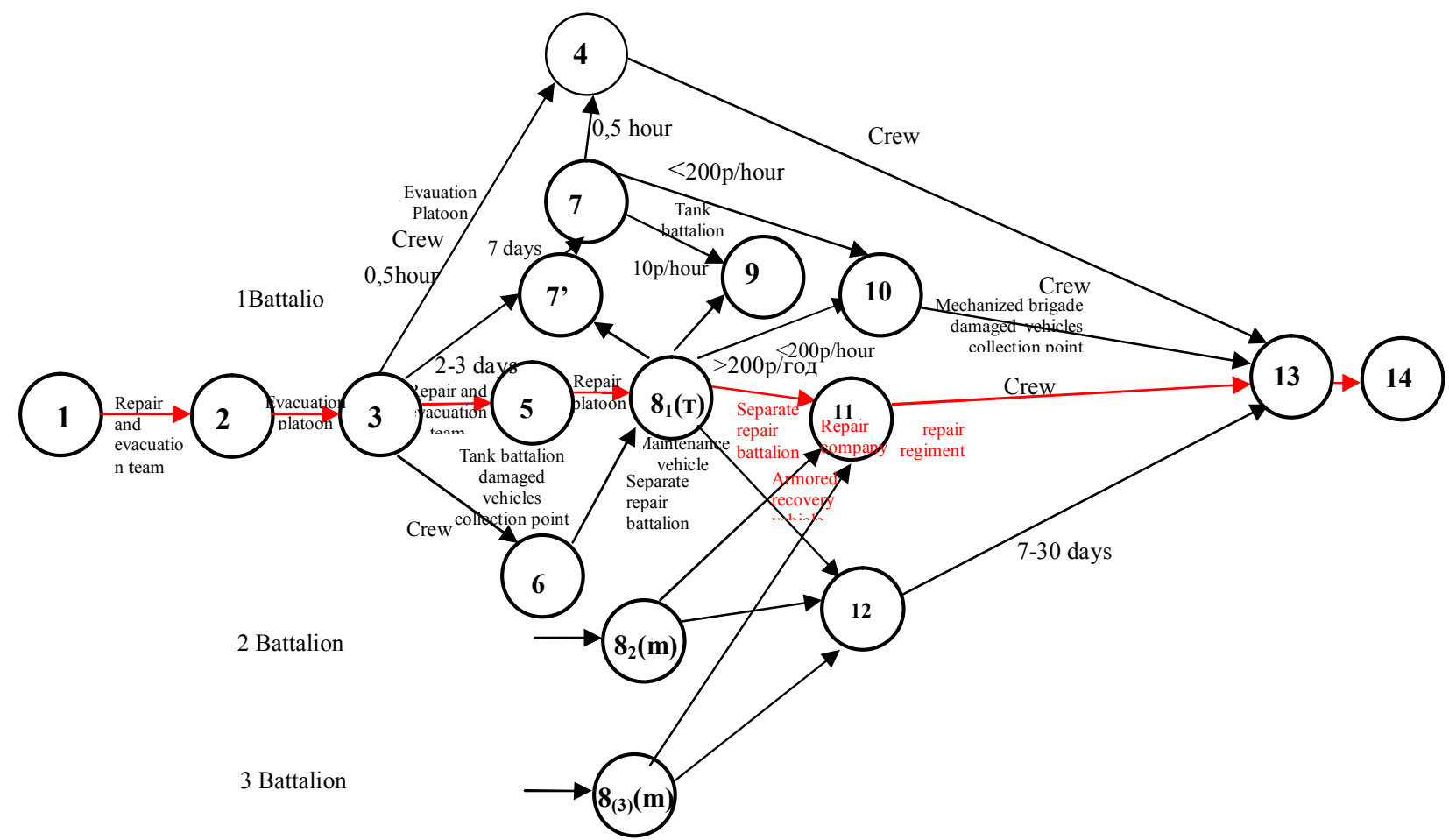

Fig. 1. Fragment of the network graph simulation of the recovery pocess of the tank (motorized) battalion 
- to create separate units of operational command logistics (for example, a logistics regiment, a separate logistics battalion), which will consist of existing car battalions, logistics battalions, and repair parts of operational commands capable of deploying mobile units in field and field environments, ensure timely transportation of material resources, repair of weapons and equipment;

- to introduce strict distribution of functions on the volume and the list of works between the links of the system in accordance with the technical equipment, qualification and specialization of the personnel of the repair and recovery units and the availability of the required number of spare parts for the volume and the list of works that are being performed.

Such distribution is proposed on the basis of functional characteristics (technical service, logistics service, supply service, transport service, medical service, etc.), which in turn will lead to a decrease in the number of intermediate supply units.

According to the authors, the reduction of the critical path will be facilitated by the introduction of an interspecific territorial system of providing military units, regardless of their affiliation with one or another type of armed forces, and concentrating their basic efforts directly where material resources are spent - in units.

It is advisable for the logistics regiment commander to interact with the commanders of the armored weapons and military equipment, maintenance and repair, as well as issues related to the AWME operation and recovery (eg through a senior brigade repair officer).

To improve the functioning of the AWME recovery system, it is proposed to clarify the norms and order of separation of rockets and ammunition stocks, transfer to the operational commands of certain arsenals, security centers, bases and warehouses, to review the nomenclature and composition of repair kits of spare parts and to create additional repair kits (typical) with a standard supply of severely deficient military-technical equipment.

In addition, it is advisable to provide the possibility of the repair and recovery units forces and means operational and combat composition adjusting according to the design of operations and the tasks defined by it.

An example of a network graph of the simulation AWME recovery pocess constructed taking into account the comments, is shown in Fig. 2.

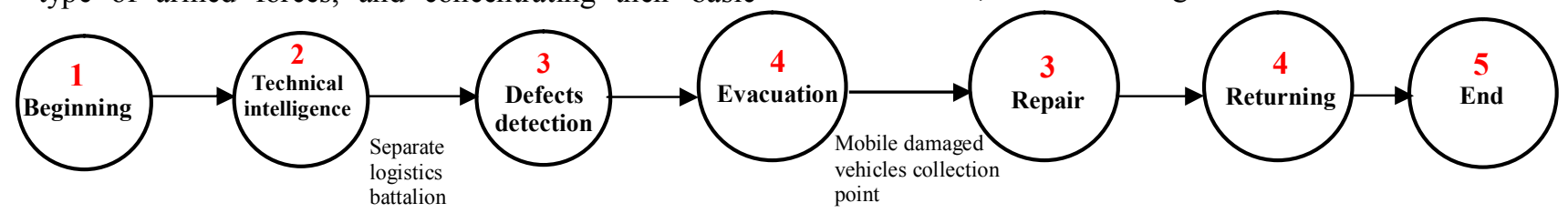

Fig. 2. Network schedule of AWME recovery with functional volume distribution and list of works

3. Optimization of the network schedule of AWME recovery according to the principles of functional volume distribution and the list of works between elements of the recovery system. As you can see, building a network schedule of AWME recovery on the principles of the functional distribution of the volume and the list of works between the elements of the recovery system makes it possible to draw conclusions about the advisability of repairing equipment at the places of failure or at the collection points of damaged combat vehicles based on: vehicles;

the least time spent on evacuation damaged

close interaction and coordination of the work of all forces and means of technical support;

performing repairs by the aggregate method.

In accordance with these principles, it is proposed to build structures of forces and facilities for the AWME field recovering.

The focus is paid to the recovering of the failed AWME at the places of failure, so most of the forces and means intended for the repair of weapons and equipment are in the military rank.

To ensure high survivability and mobility of the means of evacuation and repair, especially in units of a company-battalion-brigade operating under the influence of enemy fire weapons, modern tanks and other types of armored vehicles are used as a base for repair and evacuation forces and equipment. The main military evacuation vehicle operating directly behind combat conducting units may be an armored repair and evacuation vehicle.

Equipping troops with modern repair and evacuation vehicles will significantly increase the amount of repair work that is carried out directly in combat orders of units, accelerates the return of weapons and military equipment in order.

In the units, starting with the division, where it is necessary to evacuate damaged equipment over a long distance, heavy-duty vehicles (trailers) are comprehensively used.

\section{Conclusions}

1. The network graphic model of the for restoring armored weapons and military equipment recovery during combat operations it possible to present the entire scope of work, their logical and chronological relationship and to adjust plans taking into account the limited time and insufficient number and training of personnel.

2. Analysis of the critical path of the network schedule makes it possible to conclude that if there are several battalions in the brigade, the repair of samples of armored weapons and military equipment with a labor intensity of more than 200 people / hour is on the critical path because the forces and means for the restoration of armored weapons and military equipment not enough in modern conditions. 
3 . The network schedule for the recovery of armored weapons and military equipment with the functional distribution of the volume and list of works is optimal for the length of the critical path.

4. The improvement of the functioning of the armored weapons and military equipment recovery system offered by the strict separation of functions in terms of volume and list of work between the parts of the system, by the correspondence of the technical equipment, qualifications and specialization of the personnel of repair and restoration bodies to the availability of the required number of spare parts, volume and list of performed work.

5. The practical implementation of proposals to improve the functioning of the armored weapons and military equipment recovery system is possible by creating separate logistics units of the appropriate hierarchy levels and implementing an interspecific territorial system for providing military units in the Armed Forces of Ukraine.

\section{REFERENCES}

1. Shuyenkin V.O. (2005), "Method of estimation of losses of material means of military formations in the course of hostilities", Nauka i oborona. vol. 4, pp. 45-49.

2. Shuyenkin V.O. and Ishutin I.S. (2009), "Methods for determining the rational composition of repair bodies, taking into account the resource constraints on their creation", Nauka i oborona. vol. 3, pp. 57-62.

3. Morozov O. O. (2015), "Methods of optimal distribution of weapons and military equipment between military formations of grouping of troops", Zbirnyk naukovykh prats Natsionalnoyi akademiyi Natsionalnoyi hvardiyi Ukrayiny, vol. 2, pp. 88-91.

4. Shuyenkin V. O., Ishutin I. S. and Khazanovych O. I. (2001), Tekhnichne zabezpechennya viys $\square k$ (syl) u operatsiyi (boyu) [Technical support of troops (forces) in operation (combat)], Shaptalenko M. I. (ed.), NUOU, Kyyiv, UA.

5. Svyrydov, A., Kuchuk, H., Tsiapa, O. (2018), "Improving efficienty of image recognition process: Approach and case study", Proceedings of 2018 IEEE 9th International Conference on Dependable Systems, Services and Technologies, DESSERT 2018, pp. 593-597, DOI: http://dx.doi.org/10.1109/DESSERT.2018.8409201

6. Kovalenko, A. and Kuchuk H. (2018), "Methods for synthesis of informational and technical structures of critical application object's control system", Advanced Information Systems, Vol. 2, No. 1, pp. 22-27, DOI: https://doi.org/10.20998/25229052.2018.1.04

7. Clifford F. Gray and Erik W. Larson (2003), Project Management: the Managerial Process, Oregon State University, USA.

8. Headquarters Department of the Army (2003), Field Manual No. 4-0 Combat Service Support Washington, DC, USA.

Received (Надійшла) 11.11.2019

Accepted for publication (Прийнята до друку) 22.01.2020

\section{Обгрунтування рекомендацій щодо вдосконалення функціонування системи відновлення бронетанкового озброєння й військової техніки на основі дослідження графічної мережевої моделі}

С. А. Копашинський, О. В. Серпухов, О. А. Макогон, С. М. Губа, О. В. Ісаков, Ю. В. Бабкін, О. П. Клімов

Анотація. Предметом вивчення в статті $є$ процес функціонування системи відновлення бронетанкового озброєння та військової техніки під час ведення бойових дій в сучасних умовах. Метою дослідження є вироблення пропозицій з удосконалення функціонування системи відновлення бронетанкового озброєння й військової техніки задля скорочення часу проведення робіт та раціонального використання сил і засобів. Задачі: представити процес функціонування системи відновлення бронетанкового озброєння й військової техніки як перелік подій та робіт, що комплексно відображають його сутність та взаємозв'язки між окремими заходами; побудувати мережеву графічну модель функціонування системи відновлення бронетанкового озброєння й військової техніки підрозділів, які виконують завдання за призначенням; проаналізувати критичний шлях мережевого графіку; визначити, які роботи знаходяться на критичному шляху, потребують більш ретельного контролю та виявлення проблем та ризиків, які можуть чинити вплив на функціонування всієї системи відновлення; на основі аналізу та оптимізації мережевого графіка виробити пропозиції щодо його вдосконалення функціонування системи відновлення бронетанкового озброєння та військової техніки. Методологічною основою дослідження стали загальнонаукові та спеціальні методи наукового пізнання. Отримані такі результати. Було здійснено моделювання функціонування системи відновлення бронетанкового озброєння та військової техніки військових підрозділів під час ведення бойових дій шляхом побудови графічної мережевої моделі. Аналіз критичного шляху мережевого графіка дав змогу визначити напрямки удосконалення функціонування системи відновлення бронетанкового озброєння та військової техніки в умовах обмеження матеріальних і нематеріальних ресурсів та регулярного оновлення інформації. Висновки. Мережева графічна модель системи відновлення бронетанкового озброєння й військової техніки військових підрозділів під час ведення ними бойових дій дає можливість представити весь обсяг робіт, їх логічний і хронологічний взаємозв'язок та здійснити коригування планів 3 урахуванням обмеженого часу та недостатньої кількості і навченості особового складу. Аналіз критичного шляху мережевого графіку дає можливість зробити висновок, що при наявності у складі бригади декількох батальйонів, ремонт зразків бронетанкового озброєння й військової техніки трудомісткістю більше 200 люд/год. опиняється на критичному шляху, оскільки сил і засобів для відновлення бронетанкового озброєння та військової техніки недостатньо в сучасних умовах. Мережевий графік відновлення бронетанкового озброєння й військової техніки при функціональному розподілу обсягу i переліку робіт є оптимальним за довжиною критичного шляху. Вдосконалення функціонування системи відновлення бронетанкового озброєння й військової техніки пропонується за рахунок суворого розподілу функцій з обсягу і переліку робіт між ланками системи, у відповідності технічного оснащення, кваліфікації і спеціалізації особового складу ремонтно-відновлювальних органів і наявності необхідної кількості запасних частин обсягу і переліку робіт, які виконуються. Практична реалізація пропозицій, щодо вдосконалення функціонування системи відновлення бронетанкового озброєння й військової техніки можлива шляхом створення окремих підрозділів логістики відповідних рівнів ієрархії та впровадження міжвидової територіальної системи забезпечення військових частин у Збройних Силах України.

Ключов і слов а : відновлення бронетанкового озброєння і техніки, мережевий графік, логістичний підхід. 